\title{
DAMPAK FLY OVER MANAHAN TERHADAP ARUS LALU LINTAS
}

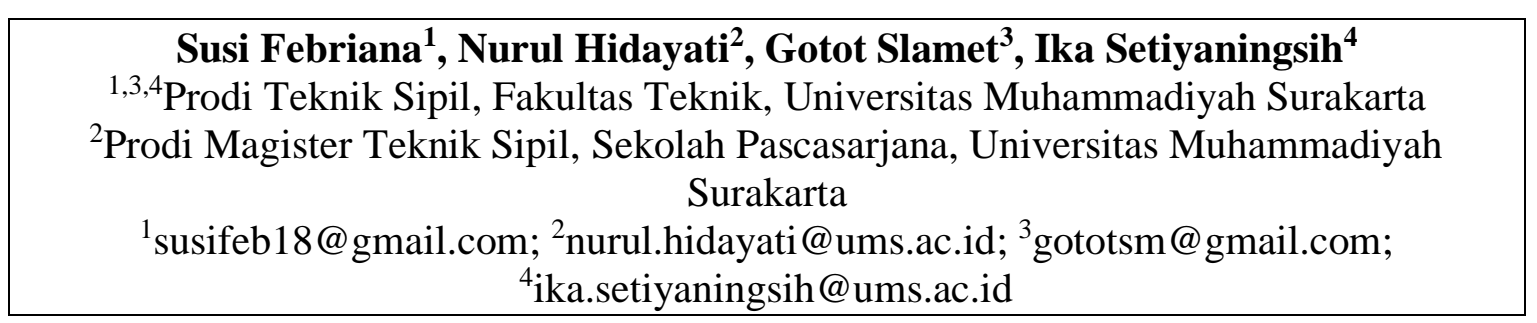

Diterima: Agustus 2019; Disetujui: November 2019

\begin{abstract}
Surakarta has several locations prone to congestion due to at grade highwayrailway crossing, one of which is in the Manahan area. The solution made by the government to overcome this problem was to build the Fly Over. Nevertheless, this condition affects the surrounding traffic condition, such as on Slamet Riyadi Street. This study aims to determine the characteristics of the traffic, and the existing performance of the road, then to compare it with the previous road performance. The primary data used are the existing condition of geometric, side frictions, volume and travel time which is then analyzed using IHCM 1997. The results show that during morning peak hour is obtained a volume of 1827.7 pcu per hour with the averages speed is $38.25 \mathrm{~km}$ per hour. The road performance expressed by the degree of saturation is obtained at 0.38. This value is smaller than before the change. This shows that the performance after the Fly Over is better than before. Nevertheless, both performances are still categorized in good condition.
\end{abstract}

Keywords: fly over, traffic characteristics, road performance

Abstraksi. Surakarta memiliki beberapa lokasi rawan kemacetan akibat adanya perlintasan sebidang antara jalan raya dengan jalan kereta api, salah satunya di daerah Manahan. Solusi yang dibuat pemerintah untuk mengatasi masalah tersebut yaitu membangun Fly Over. Meskipun demikian, hal tersebut mempengaruhi kondisi lalu lintas di sekitarnya, seperti Jl. Slamet Riyadi. Penelitian ini bertujuan untuk mengetahui kondisi karakteristik lalu lintas, dan kinerja ruas jalan tersebut saat ini, serta membandingkannya dengan kinerja sebelum perubahan. Data primer yang digunakan adalah kondisi geometrik, hambatan samping, volume dan waktu tempuh saat ini yang kemudian dianalisis menggunakan MKJI 1997. Hasil analisis menunjukkan saat periode puncak pagi diperoleh volume 1827,7 smp/jam, dengan kecepatan rata-rata waktu $38,25 \mathrm{~km} / \mathrm{jam}$. Kinerja ruas yang dinyatakan dengan derajat kejenuhan diketahui sebesar 0,38. Nilai tersebut lebih kecil dibandingkan dengan sebelum perubahan. Hal tersebut menunjukkan bahwa kinerja setelah adanya Fly Over lebih baik dibandingkan sebelumnya. Meskipun demikian keduanya masih dikategorikan dalam kondisi baik.

Kata Kunci: fly over, karakteristik lalu lintas, kinerja jalan

\section{PENDAHULUAN}

Berdasarkan data Perhubungan Darat dalam angka, Surakarta diklasifikasikan sebagai salah satu kota besar di Indonesia (Kementerian Perhubungan, 2017). Kota ini mempunyai sejumlah fasilitas umum dan sosial yang memadai. Aktivitas masyarakat Surakarta didominasi oleh perdagangan maupun tukar menukar jasa. Lokasi aktivitas tersebut hampir menyeluruh di Kota Solo salah satunya terlihat di ruas Jl. Slamet Riyadi (Wahyuningsih, 2008). Ruas jalan ini membentang dari Tugu Purwosari hingga Bundaran Gladag, yang di sepanjang jalan tersebut terdapat gedung- 
gedung bertingkat seperti Mall dan Hotel (Singgih, 2010).

Peningkatan pembangunan berpotensi menjadikan kota ini kawasan destinasi yang dapat meningkatkan perekonomian kota (Herawati dan Akbar, 2011). Dampak lain dari adanya peningkatan di atas adalah meningkatnya jumlah pergerakan manusia, baik dengan kendaraan pribadi maupun umum. Jika peningkatan pergerakan ini tidak diimbangi dengan peningkatan fasilitas maka dapat menimbulkan masalah, salah satu yang terlihat adalah adanya kemacetan.

Lokasi rawan macet di Kota Solo diantaranya: Pasar Klewer, Kawasan Singosaren, Pasar Legi, Mall Solo Square, Pusat Grosir Solo, Simpang Komplang, Nusukan, dan Joglo (Prayogo, 2011). Pemerintah Kota Solo memiliki beberapa cara untuk mengatasi adanya kemacetan tersebut di atas. Salah satunya adalah sistem satu arah (SSA) yang diterapkan di ruas jalan Jl. Agus Salim. Permasalahan lalu lintas di ruas jalan yang diatur dengan sistem ini, terkadang masih belum sepenuhnya dapat diselesaikan. Hal ini diantaranya dapat dilihat dari nilai derajat kejenuhannya, yaitu sebesar 0,84 di sekitar perlintasan Purwosari dan 0,93 di sekitar Pasar Jongke (Hidayati dkk, 2018). Akan tetapi, ketika ada ruas lain yang juga diatur dengan sistem ini (Jl. Rajiman), maka nilai di atas menurun menjadi 0,50 dan 0,68 (Wibowo, 2017a). Selain hal di atas, kemacetan di Solo juga ada yang disebabkan karena perlintasan kereta api seperti di Jebres, Balapan, Manahan, maupun Purwosari (Dhijayanti, 2012). Perlintasan sebidang kereta api dengan jalan raya merupakan area yang memiliki resiko luka parah yang tinggi jika terjadi kecelakaan (Liu dan Khattak, 2017). Solusi yang dibuat pemerintah untuk mengatasi salah satu masalah di atas (Manahan) yaitu dengan membangun Fly Over. Jenis konstruksi ini merupakan salah satu tipe simpang tak sebidang, dimana jalan raya yang menuju persimpangan dibuat pada ketinggian yang berbeda agar tidak terjadi konflik langsung antar kendaraan (Hidayati dkk, 2018).

Pemerintah, dalam hal ini Dinas Perhubungan Kota Solo, mewaspadai adanya kemacetan akibat pembangunan tersebut dengan memberlakukan sistem lalu lintas di ruas Jl. Slamet Riyadi dari Simpang Gendengan sampai Stasiun Purwosari yang sebelumnya satu arah dengan Contra Bus Flow menjadi sistem dua arah (Wibowo, 2017b). Berdasarkan pengamatan, meskipun Fly Over telah jadi, namun hingga penelitian ini dilakukan sistem dua arah masih berlaku. Oleh karena itu, penelitian ini dilakukan untuk mengetahui pengaruh Fly Over tersebut terhadap karakteristik arus lalu lintas, dan kinerja ruas jalan sekitarnya, khususnya di Jl. Slamet Riyadi. Hasil yang diperoleh pada kondisi saat ini tersebut kemudian dibandingkan dengan kinerja jalan sebelum ada Fly Over.

\section{METODE PENELITIAN}

Penelitian ini dilakukan di Jl. Slamet Riyadi Surakarta lebih tepatnya di depan Bank Mandiri Syariah. Data primer yang digunakan adalah kondisi geometrik, hambatan samping, volume dan waktu tempuh saat ini yang kemudian dianalisis menggunakan MKJI 1997. Pengambilan data dilaksanakan pada hari Rabu pukul 06.00-09.00 WIB dan 09.00-12.00 WIB. Data sebelum adanya Fly Over meliputi volume kendaraan dan kinerja jalan diambilkan dari penelitian sebelumnya (Hidayat, 2017). Paramater yang dicari 
dalam penelitian ini akan dijelaskan sebagai berikut.

\section{Hambatan samping (Side Friction, SF)}

Hambatan samping adalah seluruh aktivitas di sekitar jalan, baik di badan jalan maupun di luar badan jalan yang dapat mempengaruhi kinerja jaringan jalan (Hidayati dkk, 2019). Kondisi hambatan samping sesuai MKJI 1997 diklasifikasikan dalam hambatan Tinggi, Sangat Rendah, Rendah, Sedang, Sangat Tinggi. Penentuan klas hambatan dapat dilakukan secara kualitatif maupun kuantitatif mengacu pada ketentuan yang ada.

\section{Arus lalu lintas (Volume, Q)}

Parameter volume digunakan untuk menyatakan jumlah kendaraan yang melewati suatu lajur atau ruas jalan tertentu pada periode tertentu (Hidayati dkk, 2018). Kendaraan yang ada di jalan terdiri dari berbagai tipe dengan karakteristik yang berbeda-beda. Oleh karena itu, di dalam analisis arus lalu lintas atau volume nilai yang diperoleh dari pencacahan di lapangan perlu dikonversikan ke satuan kendaraan standar, yaitu satuan mobil penumpang atau smp (MKJI, 1997, Hidayati dkk, 2016, dan Asaithambi dkk, 2017).

Kecepatan arus bebas (free flow speed, FV)

Menurut Bina Marga dalam MKJI (1997) kecepatan arus bebas yaitu kecepatan kendaraan yang dipilih pengemudi tanpa dipengaruhi oleh kendaraan lain. Nilai FV dapat ditentukan menggunakan persamaan berikut ini: $F V=\left(F V_{0}+F V_{W}\right) * F F V_{S F} * F F V_{C S}(1)$ dengan:

$F V_{0}$ : Kecepatan arus bebas dasar.

$F V_{W}$ : Faktor penyesuaian kecepatan terhadap lebar jalan.
$F F V_{S F}$ : Faktor penyesuaian kecepatan terhadap hambatan samping dan lebar bahu.

$F F V_{C S}$ : Faktor penyesuaian kecepatan terhadap ukuran kota.

\section{Kapasitas (Capacity, C)}

Kapasitas adalah arus maksimum yang melalui suatu potongan jalan pada kondisi tertentu (MKJI,1997). Kapasitas dapat ditentukan dengan persamaan sebagai berikut:

$C=C_{0} x F C_{C W} x F C_{S P} x F C_{S F} x F C_{C S}$

dengan:

$C_{0} \quad: \quad$ Kapasitas dasar (smp/jam)

$F C_{C W}$ : Faktor penyesuaian akibat lebar jalur lalu lintas

$F C_{S P}$ : Faktor penyesuaian akibat pemisah arah

$F C_{S F}$ : Faktor penyesuaian akibat hambatan samping

$F C_{C S}$ : Faktor penyesuaian untuk ukuran kota

\section{Derajat Kejenuhan (DS)}

Nilai derajat kejenuhan atau degree of saturation diperoleh dari ratio hubungan antara volume (Q) dengan kapasitas (C). Nilai ini digunakan sebagai faktor salah satu parameter untuk menilai kondisi kinerja jalan (MKJI,1997). Nilai DS dihitung berdasarkan persamaan berikut:

$D S=\frac{Q}{C}$

\section{Kecepatan (Velocity/Speed, V)}

Kecepatan adalah gerak suatu kendaraan dalam jarak persatuan waktu (MKJI, 1997). Kecepatan rata-rata arus dapat diklasifikasikan menjadi dua, yaitu: space mean speed $\left(\mathrm{V}_{\mathrm{s}}\right)$ dan time mean speed $\left(\mathrm{V}_{\mathrm{t}}\right)$ dengan menggunakan persamaan sebagai berikut:

$$
\begin{gathered}
V=\frac{d}{t} \\
V S=\frac{d \cdot n}{\sum_{i=1}^{n} t i}
\end{gathered}
$$


$V t=\frac{\sum_{i=1}^{n} \frac{d}{t i}}{n}$

dengan:

d : Jarak tempuh

ti : Waktu tempuh kendaraan

$\mathrm{n} \quad$ : Jumlah kendaraan yang diamati

\section{Kepadatan (Density,D)}

Kepadatan yaitu jumlah kendaraan yang menempati panjang ruas/jalur jalan (Morlok, 1991). Nilai kepadatan dapat dihitung dengan persamaan di bawah ini.

$$
\mathrm{D}=\frac{Q}{V}
$$

\section{HASIL DAN PEMBAHASAN \\ Geometrik}

Geometrik adalah gambaran jalan yang disertai ukuran. Berdasarkan pengamatan dan pengukuran diperoleh data geometrik ruas J1. Slamet Riyadi Surakarta setelah adanya perubahan yaitu: tipe jalan 4 lajur 2 arah tidak terbagi dengan lebar tiap lajur bervariasi antara 3 - 4 meter. Satu lajur pada sisi Utara digunakan untuk parkir onstreet. Gambar potongan memanjang ruas jalan ini dapat dilihat pada Gambar 1.

\section{Kondisi Lingkungan}

Berdasarkan hasil pengamatan kondisi lingkungan di sekitar Jl. Slamet Riyadi Surakarta saat ini dikategorikan dalam tipe komersial. Hal ini dapat dilihat dari kondisi sekitar jalan tersebut berupa gedung-gedung bertingkat (mall, hotel, rumah sakit), sekolah dan tempat wisata. Jumlah penduduk Surakarta tahun 2019 diperoleh dengan cara memprediksi dari data yang tersedia di BPS (tahun 2014-2016) yaitu sebesar 518.721 jiwa.

Jenis hambatan samping yang terlihat di lokasi tersebut adalah: penyeberang jalan, kendaraan parkir, kendaraan berhenti, kendaraan lambat yang akan menyeberang, dan kendaraan keluar masuk dari sisi jalan. Hasil analisis hambatan samping dapat dilihat pada Gambar 2.

Gambar 2 menunjukan frekuensi hambatan samping saat ini (setelah adanya perubahan) tertinggi berada di pukul 10.1011.10 WIB sebesar 686,40 frek.bobot/jam termasuk ke dalam golongan level tinggi. Frekuensi hambatan samping terendah terjadi pada pukul 06.00-07.00 WIB sebesar 413,30 frek.bobot/jam termasuk dalam golongan sedang. Kondisi hambatan samping sebelum adanya perubahan diketahui dari data sekunder yang dikategorikan dalam level tinggi (Hidayat, 2017).

\section{Volume Lalu Lintas}

Volume lalu lintas di lokasi penelitian dibedakan menjadi 2, yaitu volume sisi Selatan dan Utara. Hasil analisis volume lalu lintas dapat dilihat pada Gambar 3, Gambar 4, dan Tabel 1.

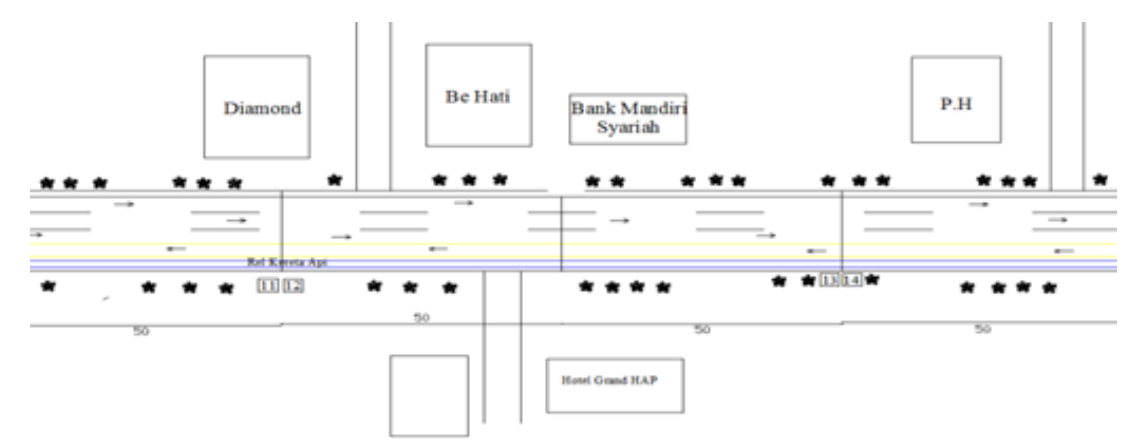

Gambar 1. Potongan Memanjang Ruas Jl. Slamet Riyadi Kondisi Saat Ini Sumber: berdasarkan hasil analisis 


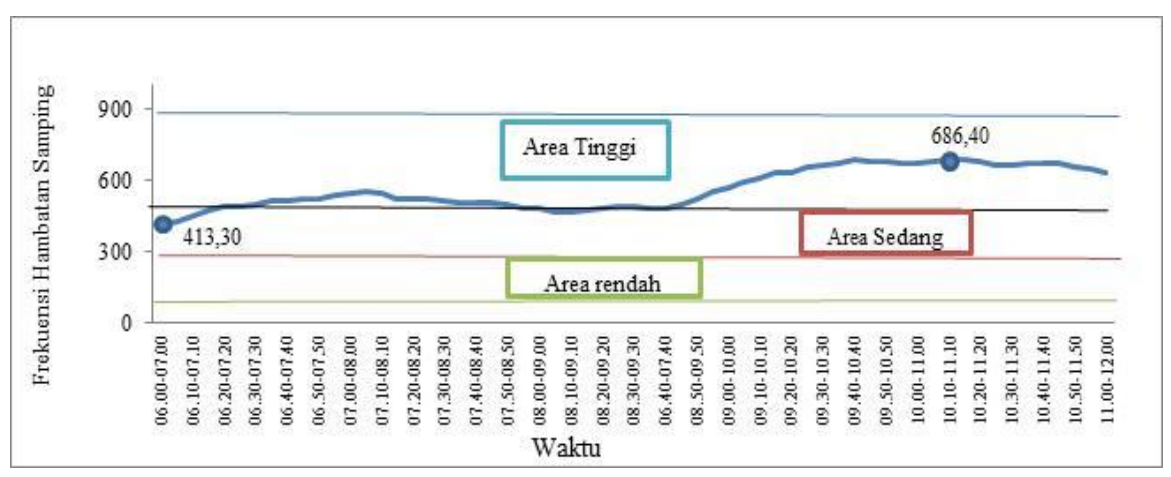

Gambar 2. Frekuensi Hambatan Samping setelah adanya Fly Over Sumber: berdasarkan hasil analisis

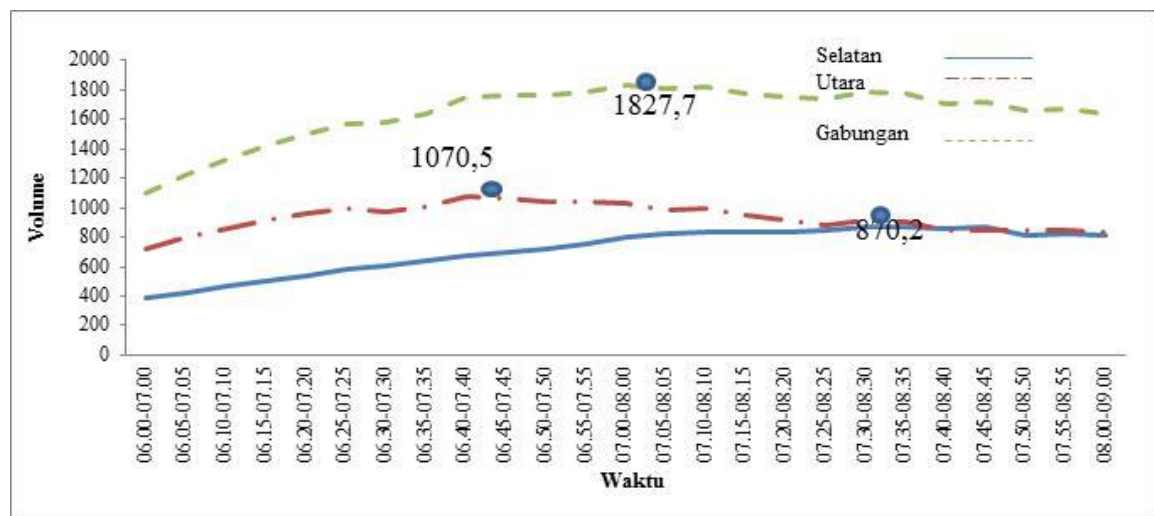

Gambar 3. Volume Lalu Lintas pada Pagi hari

Sumber: berdasarkan hasil analisis

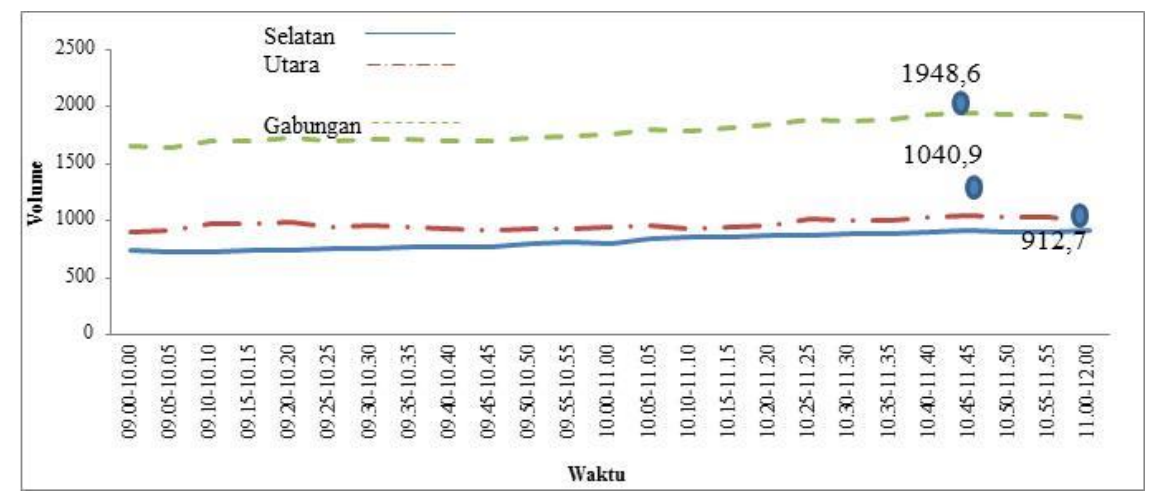

Gambar 4. Volume Lalu Lintas pada Sore hari

Sumber: berdasarkan hasil analisis

Tabel 1.

Volume Lalu Lintas

\begin{tabular}{ccccc}
\hline \multirow{2}{*}{ No } & \multirow{2}{*}{ Sisi } & \multicolumn{2}{c}{ Volume (smp/jam) } \\
\cline { 3 - 5 } & & Sebelum & \multicolumn{2}{c}{ Sesudah } \\
\cline { 3 - 5 } & & Pagi & Pagi & Siang \\
\hline 1 & Selatan & - & 870,2 & 912,7 \\
\hline 2 & Utara & 2437,7 & 1070,5 & 1040,9 \\
\hline
\end{tabular}

Sumber: berdasarkan hasil analisis
Berdasarkan Gambar 3, Gambar 4 dan Tabel 1 dapat diketahui bahwa peak volume ( $\left.Q_{\text {maks }}\right)$ per arah setelah adanya perubahan pada pagi hari terjadi pada pukul 07.3508.35 WIB sebesar 870,2 smp/jam (Selatan), dan pukul 06.40-07.40 WIB sebesar 1070,5 smp/jam (Utara). Volume puncak dua arah terjadi pada pukul 07.0008.00 (peak pagi) sebesar 1827,7 smp/jam, dan pada pukul 10.45-11.45 sebesar 1948,6 
smp/jam (peak siang). Peak volume pagi sebelum adanya perubahan sisi utara terjadi pada pukul 06.15-07.15 sebesar 2437,75 smp/jam, sedangkan sisi selatan diabaikan karena jalur Contra Bus Flow. Perubahan volume di atas bisa dikarenakan sistem yang berubah di jalan tersebut maupun di sekitarnya.

\section{Kapasitas}

Sebagaimana disebutkan sebelumnya nilai kapasitas (ruas jalan) dipengaruhi oleh beberapa faktor. Berdasarkan Rumus 2 serta nilai-nilai faktor penyesuai dalam MKJI 1997, nilai kapasitas yang diperoleh dapat dilihat pada Tabel 2.

Tabel 2. Kapasitas Ruas Jalan

\begin{tabular}{cccc}
\hline \multirow{2}{*}{ No } & \multirow{2}{*}{ Sisi } & \multicolumn{2}{c}{ Kapasitas (smp/jam) } \\
\cline { 3 - 4 } & & Sebelum & Sesudah \\
\cline { 3 - 4 } & & Pagi & Pagi dan Siang \\
\hline 1 & Selatan & - & 1170,55 \\
\hline 2 & Utara & 3629,34 & 2731,45 \\
\hline \multicolumn{3}{r}{ Sumber: berdasarkan hasil analisis }
\end{tabular}

Tabel 2 menunjukan bahwa nilai kapasitas sesudah perubahan diperoleh sisi Selatan dan Utara sebesar 1170,55 smp/jam dan 2731,45 smp/jam. Nilai kapasitas sebelum adanya perubahan sebesar 3629,34 smp/jam. Nilai kedua kondisi di atas berbeda, karena adanya perubahan pada faktor penyesuainya, seperti tipe jalan serta lebar lajur.

\section{Derajat Kejenuhan}

Berdasarkan Rumus 3, dapat diketahui nilai derajat kejenuhan dipengaruhi oleh volume dan kapasitas ruas jalan. Nilai DS yang diperoleh dalam penelitian ini dapat dilihat pada Tabel 3 .

Tabel 3 menunjukan bahwa DS setelah adanya perubahan pada pagi hari sisi Utara dan Selatan sebesar 0,38 dan 0,68, pada siang hari sebesar 0,78 dan 0,38 . Nilai DS sisi Utara lebh kecil dibanding sisi Selatan karena kapasitas di kedua sisi berbeda. Kapasitas jalannya lebih besar sisi Utara dibanding sisi Selatan. Nilai DS setelah adanya perubahan pada sisi Utara yaitu 0,38 (pagi), nilai ini lebih baik dibanding sebelum adanya perubahan yaitu 0,67. Meskipun demikian keduanya masih dinyatakan dalam kondisi lalu lintas yang stabil.

Tabel 3. Derajat Kejenuhan

\begin{tabular}{ccccc}
\hline \multirow{2}{*}{ No } & \multirow{2}{*}{ Sisi } & \multicolumn{3}{c}{ Derajat Kejenuhan } \\
\cline { 3 - 5 } & & Sebelum & \multicolumn{2}{c}{ Sesudah } \\
\cline { 3 - 5 } & & Pagi & Pagi & Siang \\
\hline 1 & Selatan & - & 0,68 & 0,78 \\
\hline 2 & Utara & 0,67 & 0,38 & 0,38 \\
\hline \multicolumn{3}{c}{ Sumber: berdasarkan hasil analisis }
\end{tabular}

\section{Kecepatan Kendaraan}

Hasil analisis kecepatan kendaraan setelah adanya perubahan dapat dilihat pada Gambar 5 dan Gambar 6. Kedua gambar tersebut menunjukan bahwa berdasarkan kondisi peak hour pagi pukul 07.00-08.00 diperoleh $\mathrm{Vs}_{\text {maks }}$ sebesar 23,53 $\mathrm{km} / \mathrm{jam}$ (Selatan) dan 38,25 km/jam (Utara), sedangkan saat peak hour siang pukul 10.45-11.45 masing-masing sebesar 30,61 $\mathrm{km} / \mathrm{jam}$ dan $34,78 \mathrm{~km} / \mathrm{jam}$. Kecepatan kendaraan lebih besar bagian Utara karena kapasitas jalannya jauh lebih dibandingkan sisi Selatan, meskipun volumenya juga lebih besar. Berdasarkan nilai kecepatan ini maka dapat dikatakan juga bahwa kinerja ruas jalan sisi Utara lebih baik dibanding sisi Selatan.

\section{Kepadatan}

Berdasarkan Rumus 7, nilai kepadatan dipengaruhi oleh volume dan kecepatan kendaraan. Hasil perhitungan kepadatan pada kondisi eksisting dapat dilihat pada Gambar 7 dan Gambar 8. Kedua gambar tersebut menunjukan bahwa kepadatan 
( $\left.\mathrm{D}_{\text {maks }}\right)$ pada saat peak hour pagi $(07.00-$ smp/km dan $29,92 \mathrm{smp} / \mathrm{km}$. Kepadatan 08.00) diperoleh sebesar $34,03 \mathrm{smp} / \mathrm{km}$ tinggi terjadi jika volumenya tinggi, (Selatan) dan 26,86 smp/km (Utara), sebaliknya kepadatan rendah saat sedangkan saat peak hour siang (10.45- volumenya rendah.

11.45) masing-masing sebesar 29,66

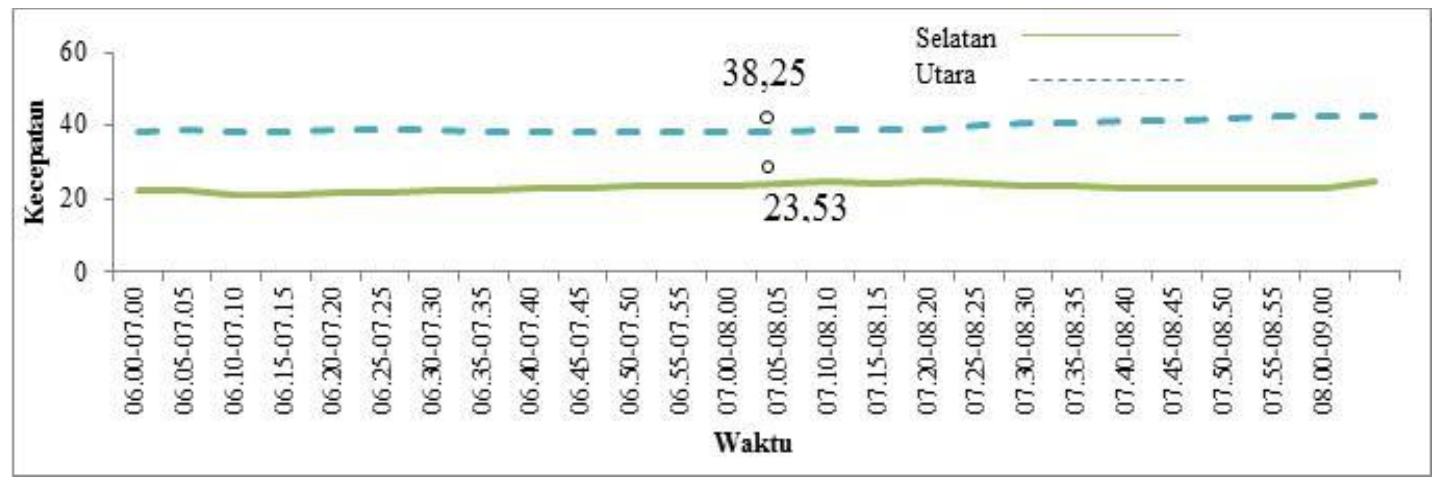

Gambar 5. Nilai Kecepatan Saat Peak Hour Pagi

Sumber: berdasarkan hasil analisis

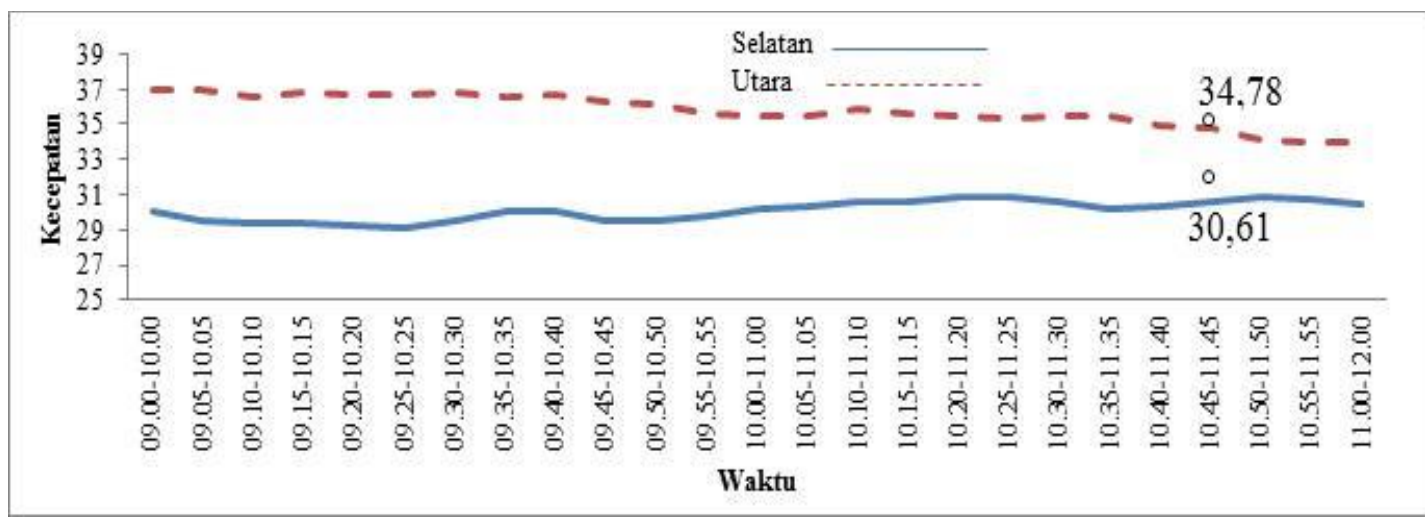

Gambar 6. Nilai Kecepatan Saat Peak Hour Siang

Sumber: berdasarkan hasil analisis

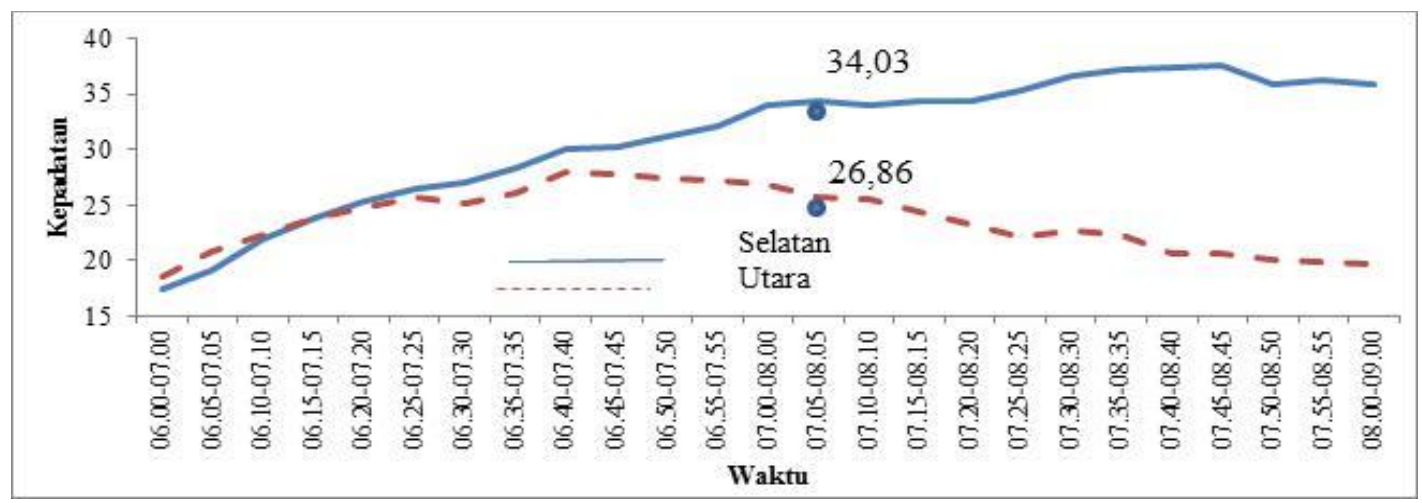

Gambar 7. Nilai Kepadatan Saat Peak Hour Pagi

Sumber: berdasarkan hasil analisis 


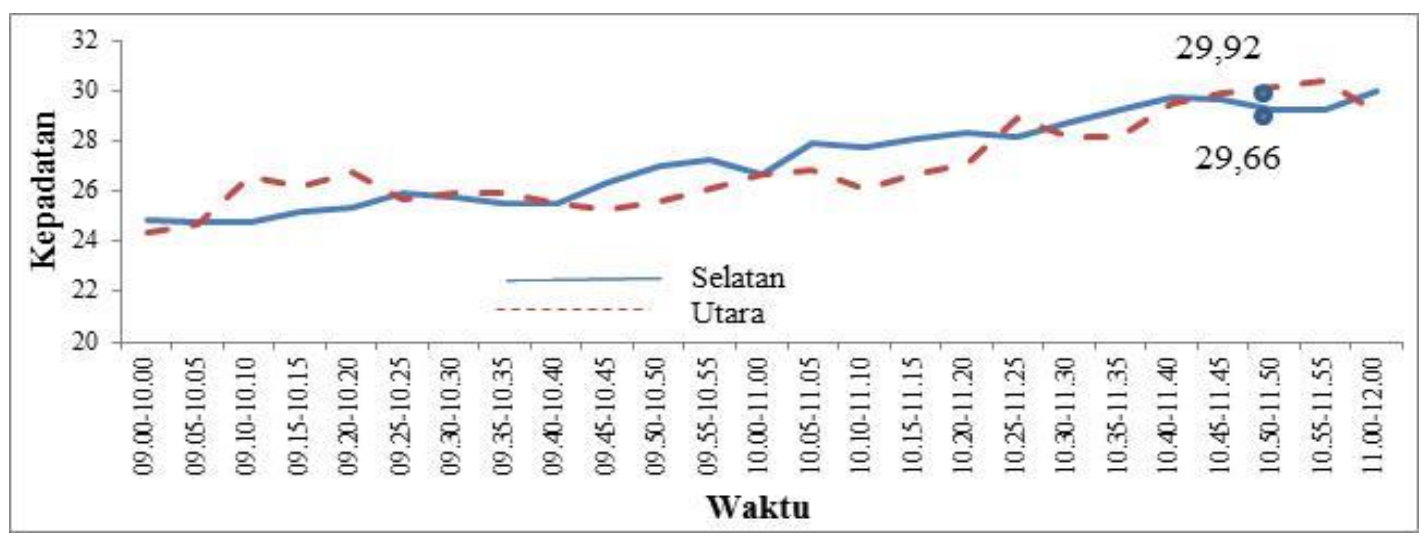

Gambar 8. Nilai Kecepatan Saat Peak Hour Siang

Sumber: berdasarkan hasil analisis

\section{SIMPULAN}

Hasil analisis menunjukkan bahwa saat periode puncak pagi diperoleh volume sebesar 1827,7 smp/jam, dengan kecepatan rata-rata waktu $38,25 \mathrm{~km} / \mathrm{jam}$. Kinerja ruas yang dinyatakan dengan derajat kejenuhan diketahui sebesar 0,38 . Nilai tersebut lebih kecil dibandingkan dengan sebelum perubahan. Hal tersebut menunjukkan bahwa kinerja setelah adanya Fly Over lebih baik dibandingkan sebelumnya. Meskipun demikian, kedua kinerja tersebut masih dikategorikan dalam kondisi baik.

\section{DAFTAR PUSTAKA}

Asaithambi, Gowri; Mourie, H. Sekhar; Sivanandan, Ramaswamy. 2017. Passenger Car Unit Estimation at Signalized Intersection for Non-lane Based Mixed Traffic using Microscopic Simulation Model. Periodica Polytechnica transportation Engineering. Vol. 45 (1), pp. 12-20. https://pp.bme.hu/tr/article/view/8986/7286

Bina Marga. 1997. Manual Kapasitas Jalan Indonesia, Direktorat Jendral Bina Marga Departemen Pekerjaan Umum. Jakarta

Dhijayanti, Agies Putri. 2012. Faktor-Faktor Yang Mempengaruhi Tingkat Aksesibilitas di Perlintasan Kereta Api Surakarta. Skripsi. Universitas Negeri Sebelas Maret. Surakarta.

Herawati, Tuty dan Akbar, Djuni. 2011. Kajian Pengembangan Potensi Wisata MICE Kota Solo Dalam Rangka Meningkatkan Daya Saing Daerah. Epigram, Volume 8, No. 2, Hal. 78-84.

Hidayat, Arif Nur. 2017. Pengaruh Perubahan Sistem Satu Arah Ruas PurwosariGendengan terhadap Kinerja Simpang Gendengan. Skripsi. Universitas Muhammadiyah Surakarta.

Hidayati, Nurul; Liu, Ronghui; Montgomery, Frank. 2016. The Development of Prediction Model of the Passenger Car Equivalent Values at Different Locations. ARPN Journal of Engineering and Applied Sciences. Vol. 11, No. 6.

http://www.arpnjournals.org/jeas/research_papers/rp_2016/jeas_0316_3876.pdf 
Hidayati, Nurul; Setiyaningsih, Ika; dan Idris, Zilhardi. 2018. Sistem Transportasi dan Rekayasa Lalu Lintas. Muhammadiyah University Press. Surakarta.

Hidayati, Nurul; Sunarjono, Sri; Awad, Saud Amjad; Magfirona, Alfia. 2019. Different Impact of Side Friction Condition on Traffic Flow Along Yosodipuro Street Surakarta. AIP Conference Proceeding 2114, 040011. https://doi.org/10.1063/1.5112440.

Kementrian Perhubungan, 2017. Perhubungan Darat dalam Angka. Direktorat Jenderal Perhubungan Darat. Jakarta.

Liu, Jun, dan Khattak, Asad. 2017. Gate-violation Behavior at Highway-Rail Grade Crossings and the Concequences: Using Geo-Spacial Modeling Integrated with Path Analysis. Accident Analysis and Prevention. Vol. 109, pp 99-112. https://www.sciencedirect.com/science/article/abs/pii/S0001457517303664

Morlok, Edward. K. 1991. Pengantar Teknik dan Perencanaan Transportasi. Erlangga. Jakarta.

Prayogo, Immanuel Teguh. 2011. Strategis Dinas Perubungan Kota Surakarta Dalam Optimalisasi Alat Pemberi Isyarat Lalu Lintas Berbasis Intelligent Transport System (APILL-ITS). Skripsi. Universitas Negeri Sebelas Maret. Surakarta.

Singgih, Edi Pramono. 2010. Penataan dan Pemanfaatan Ruang Terbuka (Open Space) Untuk Tempat Berkumpul Informal di Sepenggal Jalan Slamet Riyadi Surakarta. Journal of Rural and Development. Volume 1, No. 1, Hal. 73-88. Universitas Negeri Sebelas Maret. Surakarta.

Wahyuningsih, Menik. 2008. Pola dan Fakor Penentu Nilai Lahan Perkotan Di Kota Surakarta. Skripsi. Universitas Diponegoro.

Wibowo, Ari. 2017a. Manajemen Lalu Lintas Sistem Satu Arah Dan Contra Flow Angkutan Umum Jalan Slamet Riyadi (Bundaran Purwosari - Simpang Gendengan) di Kota Surakarta. Tesis Magister Teknik Sipil. Sekolah Pascasarjana. Universitas Muhammadiyah Surakarta.

Wibowo, Ari. 2017b. Proyek Fly Over Manahan Solo, Purwosari-Genengan Kembali 2 Arah. https://soloraya.solopos.com/read/20170917/489/852203/proyek-flyovermanahan-solo-purwosari-gendengan-kembali-2-arah. Retrieved September 17, 2017. 